UDC: 338.48:615.83

614.235

doi: $10.5937 /$ menhottur2001111K

\title{
Ethical principles of complementary medicine application in health tourism
}

\author{
Vesna Krs tić ${ }^{*}$, Sandra Živanović ${ }^{1}$ \\ ${ }^{1}$ University of Kragujevac, Faculty of Hotel Management and Tourism in Vrnjačka Banja, \\ Serbia
}

\begin{abstract}
The subject of the research is the application of certain ethical principles in the implementation of complementary medicine in health tou ris $m$ from the as pect of medical ethics and business ethics in touris $m$. The aim of the res earch is to identify theimportance of applying certain ethical principles in the implementation of complementary medicine in health tourism. Bibliographic-speculative and descriptive analytical methods were used. The research showed that the application of all ethical principles contained in the Declaration of Helsinki, the International Medical Code of Ethics and the Global Code of Ethics for Tourism is significant and justified in implementing complementary medicine in health touris $m$, given the structure of beneficiary touris ts and the range of services provided within health tourism. The potentials of complementary medicine in terms of its implementation in the corpus of health tourismare still underutilized in the Republic of Serbia, so they could be the subject of some future res earch in which the application of ethical principles contained in the mentioned documents would be an integral part of them.
\end{abstract}

Keywords: ethics, complementary medicine, health tourism JEL classification: I15, Z32

\section{Etički principi primene komplementarne medicine u zdravstvenom turizmu}

Sažetak: Predmet istraživanja je primena određenih etičkih principa pri implementaciji komplementarne medicine u zdravstveni turizam sa aspekta medicinske etike i poslovne etike u turizmu. Cilj istraživanja je identifikacija značaja primene određenih etičkih principa u implementiranju komplementarne medicine u zdravstveni turizam. U okviru rada korišćeni su bibliografsko-spekulativni i deskriptivni analitički metod. Istraživanje je pokazalo da je primena svih etičkih principa sadržanih u Helsinškoj deklaraciji, Internacionalnom medicinskom etičkom kodeksu i Globalnom etičkom kodeksu za turizam značajna i opravdana pri implementiranju komplementarne medicine u zdravstveni turizam, s obzirom na strukturu turista korisnika i asortiman usluga koje se pružaju u okviru zdravstvenog turizma. Potencijali komplementarne medicine po pitanju njene implementacije u korpus zdravstvenog turizma su još uvek nedovoljno iskorišćeni u Republici Srbiji našoj zemlji, pa bi mogli biti predmet nekih budućih is traživanja u okviru kojih bi primena etičkih principa sadržanih u pomenutim dokumentima bila njihov sastavni deo.

Ključne reči: etika, komplementarna medicina, zdravstveni turizam JEL klasifikacija: I15, Z32

*vesnak16@hotmail.com 


\section{Introduction}

The modern mind man (homo sapiens recens) of unchanged qualities, potentials and possible realizations of his mental totality, has been present on our planet for five to seven thous and years. The adoption of this axiomis a fundamental starting point for understanding the past, and well-known civilizations, and man as the sole creator of all cognition. It is also a condition for us to understand not only ourselves as an inimitable specialty, but als o ethics as a science and theory of morality.

The twentieth century brought contemporary views on the value of human life and established the aspirations of a third millennium man. Ethical teachings of the twentieth century based on new qualities have transformed and further transformed relationships in the community (Nenadović, 2007).

Health is one of the oldest, lasting and, in modern conditions, one of the strongest motives of tourist movements. Contemporary health touris $m$ is a form of tourism undertaken for the purpose of maintaining, enhancing and restoring impaired physical and mental well-being through natural healing factors (mineral s prings, climate, healthy drinking water, etc.), health services, sports and recreational and wellness facilities (Zečević, 2004). Bearing in mind the importance of health tourism, it is evident that the future development and diversification of Serbia's tourism offer should include this component. On the other hand, a question that remains to be considered concerns the direction, or component, of health touris m. The problem of health touris $m$ development is complex and covers a wide range of possible services (Živanović \& Krstić, 2018).

In the third millennium, with the tremendous advances in technological standards and research in the various sciences, especially medicine, which we are witnessing, people still give greater credibility to complementary than official medicine in terms of safety and costeffectiveness. It is evident that there is pronounced popularity and the need for the application of complementary medicine in the economically underdeveloped and developed part of the world (Oumeish, 1998). The application of complementary medicine, its techniques and procedures in countries in transition, must be subject to special quality control of the product, due to the lack of adequate quality standards and legislation in this field. Therapies applied in the field of complementary medicine should comply with the ethical principles of medical practice (Anders on et al., 1996).

The subject of this research is the application of certain ethical principles in the implementation of complementary medicine in health tourism from the aspect of medical ethics and business ethics in touris $m$. The aim of the research is to identify theimportance of applying certain ethical principles in the implementation of complementary medicine in health tourism. A combination of different methods was used in the study. In the data collection stage, a bibliographic-speculative method based on reference sources and literature was used. In addition to the method mentioned above, the research is based on a descriptive analytical method.

\section{Literature review}

Contemporary ethics is most concerned with contemporary philosophy. The complexity of life in the current time, es pecially at the beginning of the 21 st century, and the development of other disciplines that deal with the study of man and all his values closely link contemporary ethics with many sciences. The sciences with which contemporary ethics is most closely linked are on one side social, technical, natural, and especially, medical sciences. The task of ethics as a philosophical science of morality is to penetrate into every 
moral action. By adopting ethical attitudes, the physician and the healthcare professional should further their ethical ideal in the context of the particularities of medical ethics - to preserve human life - as a primary premise. Ethics should contribute to the understanding that ethical and moral values vary fromcivilization to civilization, but also during the same civilis ation epoch. Ethics in practice proclaims and formulates publicly - codifies certain professional obligations and duties through written documents called codes. Codes of ethics for health care professionals, journalists, lawyers, bar associations, etc. are known. By codifying the social organization, professional associations and society as a whole put themselves in a position to regulate themselves. Violation of codified principles entails accountability within a professional org anization, say, through a court of honor. Sanctions include reprimand, public stamping or exclusion from that branch organization. Sanctions, bans on practicing the profession, or bans on dealing with patients for doctors were also established. Finally, the moral rules and norms introduced into the codes are not permanent and unchanging, they change and evolve over time. Codified principles are of limited value, valid for the time for which they were enacted and socially regulated. Due to changing living conditions and social organization, there is a need to change previously adopted and codified ethical principles, which implies and justifies revisions of codes of ethics (Nenadović, 2007).

Health touris mis a journey aimed at obtaining health care. As a promising new branch of the touris mindustry, health tourismallows users to solve their health problems when traveling on vacation and enjoying the beauty of a tourist destination. In the past, touris ts mostly "stayed" in nature and were passively subjected to natural elements. Today, touris ts literally "consume" nature and have very active influence on all the natural elements of the resort. Almost all types of tourism, especially mas stourism, strongly influence the change and degradation of natural res ources. Therefore, it is necess ary for the further development of tourism activities to be carried out on the principles of sustainable development (Gligorijević, 2013). "Touris mdevelopment has an impact on creating different positive and negative environmental effects. Tourism brings foreign exchange flow that strengthens economic development and improves the national economy. However, touris mals o brings all those negative consequences, that can affect sustainable localcommunity growth, unless its development is being taken care of. In this way, the tourism can develop significant consequences, some being devastating for surroundings and the environment it is operating in. The cause of this are uncontrolled negative effects on the elements of na tural living environment, such as air, water, soil, flora and fauna" (Trišić et al., 2018, pp. 1599-1600).

Today, scientific medicine, based on the knowledge of the advanced sciences and traditional -alternative medicine, is equally persis tent. Treatmentand treatment methods and procedures that do not belong to scientific or official medicine, and are not taught at colleges and medical schools, are clas sified as traditional medicine. "The various types of complementary, alternative, unconventional, and integrative medicine in the Old World include the his torical, cultural, social, traditional, and philosophical aspects of different civilizations that predominated, mainly in Asian, African, Far Eastern, Middle Eastern, and Arab countries. Most of these types of medicine are still in use today. Many understand that taking into account not only individually physiological and biological conditions, but including psychological, social, ecological and even parallel spiritual dimensions, may reveal the underlying contributing factors to the disease" (Oumeish, 1998, p. 1373). Traditional medicine has a significant place and a number of countries have made significant strides in trying to define the legal framework, as well as experience in the field of regulation of this supplementary or alternative medical branch (World Health Organization, 2005).

Integrative medicine is a new direction in medicine that was created in response to the limitations, primarily of official, allopathic medicine, but also of some branches of complementary and alternative medicine. Integrative medicine involves the use of the best 
pos sible treatments and procedures of scientific, allopathic medicine combined with the best complementary and alternative medicine (CAM) methods based on the individual needs of the patient. It integrates, or connects, both medical systems, adapting them to the individual, and using the safest, least invasive and cost-effective approach, integrating them into a holistic understanding of the individual. In its definition of health, the World Health Organization (WHO) emphasized that "health is a multidimensional phenomenon of dynamic equilibrium in which the relationship between an individual and his or her environment, both social and physical, must be understood as integral (holistic)" (World Health Organization, 2002). The basic meaning of an integral (holistic) approach to the advancement of human health is to use the best methods and procedures of official (so-called western, official) and traditional (alternative, complementary) medicine in order to as sist the client in the best possible way. Alternative Health Promotion Technologies is a term that refers to the health technologies of traditional, complementary and alternative medicine. By this name, according to prof. Stambolovic, emphasis is given to the theoretical uniqueness of health technologies, which, in their therapeutic effect, are oriented primarily to strengthen the body's self-renewing potential (Stambolović, 1986). The demands and needs of healthcare users worldwide, as well as WHOrecommendations, point to different alternative medicine technologies as a significant health care resource (Jović \& Stambolović, 2013). Therefore, the need to integrate these health technologies into official health care systems becomes a legitimate is sue for national health policy (Sokolov Milovančević et al., 2019). There is still a discrepancy between experiential and statistically documented evidence of the efficacy and effectiveness of alternative medical treatments. This is understand able in some ways, given the paradig matic differences between alternative and biomedicine, as well as the lack of, or very scarce, funds to fund scientific res earch on alternative medicine and the holis tic model of health and disease (Sharma, 1992).

WHO es timates thatbetween 65 and $80 \%$ of the world's population uses alternative medicine as the primary form of health care (World Health Organization, 2002). More than half of the population in Germany and America use some form of traditional treatment, and in the UK $64 \%$ of government offices provide this type of healthcare. In Australia, $80 \%$ of physicians recommend acupuncture and meditation to their patients, and one quarter of physicians have received training in one or more alternative treatment techniques. Switzerland became the first country in Europe in 2009 to guarantee the right to complementary medical treatment under the Constitution, meaning that complementary medicine technologies are included in the basic package of healthcare services and funded by health care funds (Rist \& Schwabl, 2009; Studeli, 2009). All medicalsystems that view man as energy, which is an indivisible part of everything else that exists, are called by one name holistic medical systems. At the heart of holis tic therapeutic approaches is faith in man and counts on the wisdom of a body capable of self-healing. "The physician cures, but it is nature that heals" is an old Latin saying. It is believed that every person has self-healing power that needs to be released, or directed towards healing, balancein the body in case of various health disorders (Bašić \& Jović, 2011).

Alternativemedicine is not a substitute for official medicine, but provides additional health and healing options. By embracing the principle of wholeness, alternative medicine understands people as individuals and views human suffering as an expres sion of pers onal and family history. Accordingly, as sistance and support are also individualized. Human suffering cannot be understood by is olated observation of org ans and symptoms, which is led by the partialization of official medicine. The full meaning of certain health disorders becomes clear only by inclusion in the whole, both the organism itself and its context (environment, family, socialnetwork, living conditions, etc.). A holis tic approach starts from the basic idea that the body, mind and spirit form an indivisible whole and that the individual 
is firmly connected to the environment, family, society and the world in which he or she lives. Holis tic attitudes in healing are based on the assumption that the state of health is a reflection of the dynamic balance of body-mind-spirit, and that no segment is viewed as an is olated entity. It should be borne in mind that submission to any holistic method entails a change in lifestyle, including most commonly a change in eating habits, as well as how the client thinks abouthims elf and the environment that surrounds him. In order to choose the conventional or alternative method of health or healing promotion that best suits us, we need to know beforehand what the basic features and approaches that these methods entail (Hellinger \& Hevel, 2010).

In the Republic of Serbia, the Law on Health Care defines health care as an organized and comprehensive activity of a society with the primary goal of achieving the highest level of protection of the health of citizens and families. Health care, within the meaning of this Law, includes theimplementation of meas ures for preserving and improving thehealth of citizens, preventing, suppressing and early detection of diseases, injuries and other health disorders and timely and effective treatment and rehabilitation. Human rights and values in health care imply that every citizen has the right to exercise health care while respecting the highest possible standard of human rights and values, that is, has the right to physical and psychologicalintegrity and to the safety of his personality, as well as respect for his moral, cultural, religious and philosophical beliefs. Given that the goal of health care is to "achieve the highest level of protection of the health of citizens and the family", attempts to combine the knowledge and experience of so-called official and traditional (complementary) medicine in this interest are given their full meaning and importance (National Assembly of the Republic of Serbia, 2019).

The Code of Ethics is a set of formal and informal principles, schemes, regulations and good practices in business conduct. Bus iness ethics defines desirable ru les of business conduct that are the framework for action that is allowed or not allowed, but also indicates the basic rules of moral action of the person (Ris tić, 2004). Corporate Social Responsibility means acting through the offering of socially beneficial services with a minimum detrimental effect whose consequences are economically acceptable over a long period of time. The significant link between business ethics and socially res ponsible business that characterizes the global world market is an es sential component of the tourism economy. "In today's fast-changing tourism market, the only opportunity to compete for a tourist destination is through the offering of a sus tainable tourismproduct. Sustainable development goes hand in hand with the concept of socially responsible business" (Golja \& Kristinić Nižić, 2010).

Articles 3, 4 and 5 of the Global Code of Ethics for Tourism deal with Corporate Social Responsibility: Tourism, a factor of sustainable development; Touris m, a beneficiary of the cultural wealth of mankind and a factor in promotion and Tourism, a work that benefits host states and as sociations. Article 5 states that the tourismbusiness should be an integral component of the "local economic and social fabric". The last point discusses the need to explore the impact of tourism development projects on the environment and nature by professionals in this field, who, with the greatest possible transparency and objectivity, should provide, information on theirfuture programs and their foreseeable consequences. Touris mprofes sionals should foster dialogue about the content of their future programs with the population involved (Buzar, 2015).

\section{Research instruments and methods}

Within the research, a combination of different methods was used. In the data collection stage, a bibliographic-speculative method based on reference s ources and literature was used. In addition to the method mentioned above, the research is based on a descriptive analytical 
method. The first part of the paper presents a theoretical framework using a bibliographicspeculative method using a large number of literature sources of domestic and foreign literature, as well as internet sources. The research work involved different methods. Of the analytical, the method of analysis, abstraction and deduction was used.

\section{Results and discussion}

The ethical peculiarity of the practical application of medical knowledge and skills arose and developed at the same time as the emergence and development of h umanemedicine. Modern medical ethics has imposed the principles, duties and moral obligations of the medical profession, and there is a need for uniformity in this field for all physicians in the world. The result is the formation of world organizations, such as the World Health Org anization and the World Medical Association at the United Nations, the formulation of codes, declarations, resolutions and declarations binding on all countries, or doctors on all continents and all countries. Contemporary medical ethics implies continuous, further development in line with the development and achievements of scientific medicine and increasingly sophisticated medical technology, and the basic principle binding on the physician is: "My patient's interest will always remain my primary concern"(Nenadović, 2007). Deontology in medical practice implies all the obligations of professional persons arising from moral norms and commandments, which are related to the duties and rights of all pro fessions in medicine (physicians, dentists, pharmacists, healthcare professionals, administrative workers in medicine).

Es tablishing a positivefeedback link between morality and law, reflected in the application of adequate legal norms, is the key to addressing potential medical and dental dis orders in the application of complementary medicine.

Law on Health Care of the Republic of Serbia 2005 in Chapter XII, "Traditional medicine", Articles 235, 236 and 237 regulated the field of traditional medicine. The latest Health Care Law of the Republic of Serbia was adopted in early April, 2019. In Chapter XX, Complementary Medicine, Articles 217 and 218 govern this area. Article 217 states that Complementary medicine, within the meaning of this Law, includes those traditional and complementary methods and procedures of prevention, diagnostic evaluation, treatment, nursing and rehabilitation (hereinafter: complementary medicine), which have a beneficial effect on human health or their state of health, and which, in accordance with applicable medical doctrine, are not covered by the methods and procedures of conventional medicine.

The diagnostic assessments referred to in paragraph 1 of this Article entail a set of methods and procedures of complementary medicine used to diagnose the disorder, which are not based on conventional biological mechanisms and cannot serve for the diagnosis of dis eases in conventional medicine. The education of health professionals for performing methods and procedures of complementary medicine shall be conducted in accordance with the provisions of this Law related to continuing education. Article 218 states that "only those methods and procedures of complementary medicine are allowed which:

1) do not harm health;

2) do not discourage the patient from using conventional medicine methods and procedures;

3) are performed in accordance with recognized standards of complementary medicine.

Methods and procedures of complementary medicine may be performed in a health care institution or private practice, in accordance with this Law and regulations adopted for the implementation of the Law by a health worker, to whom the Minister has is sued a permit to carry out certain methods and procedures of complementary medicine." 
The Minister, on the proposal of the Republican Expert Commission on Complementary Medicine, prescribes more detailed conditions and manner of performing methods and procedures of complementary medicine in a health institution, other legal entity, or private practice, as well as a program of professional training of health workers for performing methods and procedures of complementary medicine (National Assembly of the Republic of Seriba, 2019).

According to the current Rulebook on closer conditions, methods and procedures for performing methods and procedures of traditional medicine, adopted in 2018, the methods and procedures are clas sified into 13 groups of methods of prevention, diagnosis, treatment and rehabilitation:

1. Ayurveda;

2. Acupuncture and related techniques (needless point and meridian stimulation);

3. Traditional Chinese Medicine;

4. Homeopathy;

5. Phytotherapy;

6. Quantum medicine and related techniques;

7. Chiropractic and osteopathy;

8. Reiki method;

9. Traditional home medicine;

10. Macrobiotics for medical purposes;

11. Aroma therapy for medical purposes;

12. Apitherapy for medical purposes;

13. Qi Gong Exercise, Yoga Exercise, Hata Yoga Exercise and Tai Chi Chuan Exercise for Medical Purposes.

A doctor of medicine and a doctor of dentistry, with appropriate education, can perform all methods. Pharmacists and other healthcare professionals have limitations; Master of Pharmacy can produce phy totherapy, homeopathic and traditional home remedies and apply methods fromitems 10-13. Second Healthcare Professional-having completed the relevant higher or secondary school of health profession with appropriate education, performs methods of complementary medicine frompoints 10-13 (Minis try of Health of the Republic of Serbia, 2018).

Individual authors (Zečević, 2004) consider that there are three types of health tourism: healing (only healing and one form of recovery), curative (representing rehabilitation) and wellnes s (focused on what it means: in a healthy body a healthy mind, that is, a good state of mind and body) (Cohen \& Bodeher, 2008). Wellness touris m is a new term that means the univers al offering of conditions and procedures for achieving optimal phy sical and spiritu al well-being of individuals. The wellness offer can be realized without the use of natural healing elements and without the supervision of a doctor. Spa touris mis defined as a type of complex health and tourismactivity that is carried out in natural spas, in which the treatment and rehabilitation of various dis eases and illnes ses, recovery and prevention of diseases with the professional application of naturalhealing elements and procedures of physical medicine and rehabilitation play a key role. A special category is also hos pital or medical tourism, which are trips undertaken by individuals for the purpose of hospital treatment and performing certain medical procedures (for example, surgical, dental, etc.). Detailed concepts of wellness megatrends characteristic of wellness and spa philosophy can be found in the literature (Berg, 2008). These are health, long life, individuality, the predominance of women in the spa, modern spirituality and the movement for health. From the aspect of spa innovation, an analysis of the five most important megaturist spatrends is necessary (Abram \& Kosińska, 2016). These are: Mediterranean spa, spa, wellness, ethno spa, eco spa. In 
addition to the wellness phenomenon, innovations in spa tourism health services should concentrate on the application of modern medical technologies and therapeutic cosmetic treatments. Also, this innovative approach should be enriched with elements of culture, tradition and ethnomedicine in resorts, to a greater extent than previously with ecology (Berg, 2008).

In the context of the accelerated globalization of everyday cultural values, es pecially the rise of international trade and touris $\mathrm{m}$, differences in people's cultures are becoming increasingly visible, as a potential source and cause of the unethical behavior of participants in these world events. The tendency to satisfy economic interests abovecultural ones creates negative trends. Such bad influences can be minimized by strengthening cultural interests in behavioral models of both tourists and domicilians. One way of emphasizing the importance of an acceptable and conventional form of such communication and interaction is by codes of ethics, which are intended to remind, in a particular cultural form, the respect for true values in tourist movements (Triš ić \& Štetić, 2019). The touris mindustry promotes codes of conduct as a set of expectations, behaviors and rules, writ ten by large and significant market entities, with a particular focus on culture and the environment, through a form of sustainable development (Presbury \& Edwards, 2010; Veljković \& Živković, 2018). Codes for tourists are everyday cultural guides that emphasize the type of travel behavior. The bas is of the tourist codes is the general culture, as well as the relation to natural resources, language, indigenous population, cultural heritage, acceptable behaviors and customs. Codes of ethics make full sense only if tourists are aware of their importance. The Code should remind touris ts of an acceptable and cultured way of behaving in a tourist destination, so that its core values with all geographical, cultural and social characteristics can be experienced at the s ame time. Tourismethics and appropriatecultural codes should be as universal as possible (Pokrajac \& Štetić, 2017).

United Nations World Touris m Organisation(UNWTO) is the creator of the Global Code of Ethics forTourism. "UNWTO The Global Code of Ethics for Tourism is a complete set of principles aimed at leading tourism development stakeholders. It is addressed to governments, the private sector, communities and tourists, with the goal of helping to maximize the benefits of tourism while reducing its potentially negative impact on the environment, cultural heritage and societies around the world. Although not legally binding, the Code has a mechanism for voluntary implementation through its recognition by the World Tourism Ethics Committee (WCTE), an independent and impartial body to which interested parties may submit questions regarding the implementation and interpretation of the document. The ten principles of the code cover the economic, social, cultural and environmental components of tourism" (MINT, 2014). These are: the contribution of tourism to mutual understanding and appreciation among people and societies, tourismas a means of individual and collective fulfillment, touris mas a factor of sustainable development, touris $m$ as a beneficiary of the cultural heritage of humanity and a factor in its promotion, touris $m$ as a useful activity for the countries of the community and the host, obligations of independent tourism professionals responsible for development, the right to tourism, freedom of movement, rights of employees and entrepreneurs in the tourism industry and implementation of the Global Code of Ethics for Tourism(UNWTO, 1999).

When it comes to health tourism, the ideal solution for the application of traditional-medical methods of diagnosis and treatment, as well as rehabilitation, are spa-climatic spas, which structurally represent the ideal combination of health resorts and tourist facilities. The structure of spa and climate resorts enables the functional fusion of two very powerful human activities of the third millennium - health and tourism. Ethics in practice proclaims and publicly formulates - codifies certain professional obligations and duties, through written documents - codes, which put social organizations, profes sional as sociations and 
society as a whole in a position to regulate themselves. The application of the ethical principles proclaimed by the International Medical Code of Ethics, as well as the Global Code of Ethics for Tourism, guarantees the safe and effective implementation of complementary medicine in health tourism. Modern medical ethics, based on four basic principles: the principle of respect for life, the principle of fairness (non-discrimination on any basis), the principle of charity (humanity) and the principle of respect for the patient's personality, is the starting point for the application of adequate ethical principles in incorporating complementary medicine into health tourism. The significant link between businessethics and socially responsible business characterizing the global marketplace that offers services that are useful to society and possible harms minimized, so that the long-term consequences of these harms are not unacceptable, is a respectable component of applying adequate ethical principles when incorporating complementary medicine into health touris $m$. The reconciliation of a strict medical ethical stance on the prohibition of experimentation under any human condition, and a reasoned scientific stance on the inevitability of biological experimentation as a basis for the advancement of medical science, was achieved in the Declaration of Helsinki, according to which biological experiment is allowed only by volunteers if it extends medical knowledge and realizes an immediate benefit to a sick pers on. The Declaration of Helsinki regulates the ethical principles of the human therap eutic experiment and they are much more lenient. The use of new therapeutic methods is forbidden if the same success can be achieved by existing ones.

The Declaration of Helsinki elaborates on the following principles of a clinical experiment. Clinical experiments may only be performed by scientifically qualified pers ons, who have already demonstrated a high level of expertise and moral maturity, and if they have been repeated several times in animals or in experimental laboratories and guarantee the success of its application to humans. A proportionate relationship between goal and risk is necess ary when conducting a clinical experiment. It is unacceptable to allow a banal disease to be cured through experiment, without the ris k being high, or even endangering the health or life of the patient. The Declaration of Helsinki gives the basic principles for biomedical research in general, and then the principles for diagnostic-therapeutic (clinical) and non-therapeutic (non-clinical) biomedical research. In addition to relying on the principles presented in the Declaration, guidelines for their application in biomedical research used to achieve standards in the implementation of complementary medicine methods in health tourism, as part of this research, must equally apply the InternationalMedical Code of Ethics and the Global Code of Ethics for Tourism. Article 2 of the Global Code of Ethics for Tourism discusses the prospects for tourism development: Tourism, as a means of collective and personal fulfillment, says in point 4: "Travels for religious, health, educational and cultural purposes, or for exchange purposes for language learning, are particularly useful forms of tourism, which deserve to be encouraged." Article 6 of the Global Code of Ethics for Tourism, referring to the Obligations of Participants in Tourism Development, states in paragraph 2: "Depending on them, touris mprofessionals, in cooperation with public authorities, should show concern for the safety, accident prevention, health protection and food security of those seeking their services. They should also ensure that there are adequate insurance and assis tance systems in place; should accept the reporting obligations laid down in national regulations and pay fair compensation in the event of non-compliance with their contractual obligations" (UNWTO, 1999).

\section{Conclusion}

Continuous improvement of the behavioral awareness of tourists within the framework of sustainable tourismdevelopment of health tourism is one of the tasks of planning touris $m$ development of this form of touris $m$ worldwide. In order to integrate this activity into the 
general health-tourismand social development, it is necessary to continuously inform and educateall tourist entities on the correct and ethically acceptable form of using resources in tourism. Given that health tourism resources, especially in the field of complementary medicine, are still insufficiently recognized and used by tourists, particular attention should be paid to touris mplanning and commercialization of these tourismresources in accordance with generally accepted ethical principles of sustainable touris m development. By applying the process of health-tourist emancipation, it is necessary to minimize potential conflicts between the guest, the host and the environment in this interaction. One model of successfully overcoming these conflicts is the positive impact of adequate codes of ethics on the development of a health tourism behavior culture.

When it comes to research on the ethical principles of the application of complementary medicine in health tourism, we can conclude that the application of all the principles contained in the Declaration of Helsinki, the International Medical Code of Ethics and the Global Code of Ethics for Touris m, is very significant, given the structure of beneficiary touris ts and the range of services provided within health tourism. Balneo-climatic s pas are an ideal solution for the application of complementary-medical methods of diagnostics, treatment and rehabilitation, as well as for the application of complementary-medical methods within their rich wellness tourist offer. Establishing a positive feedback link between morality and law, reflected in the application of adequate legal norms, is the key to addressing potential medical and dental disorders in the application of complementary medicine. Modern legal norms, in general, better, more justly and effectively regulate community relations than moral norms can. Compliance with the applicable legislat ion in the field of complementary medicine will greatly contribute to the adequate implementation of the ethical principles contained in the medical code of ethics relating to this field.

The potentials of complementary medicine in terms of its implementation in the health touris mcorpus are still underutilized in our country, so they could be the subject of some future res earch within which the application of ethical principles contained in the mentioned documents would be an integral part of them.

\section{References}

1. Abram, M., \& Kosińska, A. (2016). Ośrodki spa $i$ wellness. Organizacja $i$ funkcjonowanie [Spaand wellness centers. Organization and functioning]. Kraków: Wyd. AWF.

2. Anderson, I. B., Mullen, W. H., Meeker, J. E., Khojasteh-Bakht, S. C., Oishi, S., Nels on, S. D., \& Blanc, P. D. (1996). Pennyroyal toxicity: measurement of toxic metabolite levels in two cases and review of the literature. Annals of Internal Medicine, 124(8), 726-734.

3. Bašić, S., \& Jović, S. (2011). Savremeni koncept i definicije zdravlja. U Socijalna medicina sa epidemiologijom i higijenom [Modern concepts and definitions of the health]. Niš: Medicinski fakultet.

4. Berg, W.(2008). Gesundheitstourismus und wellnesstourismus [Health tourism and wellness tourism ]. München: Oldenbourg Yerlag.

5. Buzar, S. (2015). Analiza globalnog etičkog kodeksa za turizam u konteks tu društveno odgovornog poslovanja [Analysis of the global code of ethics for touris $m$ in the context of corporate social responsibility]. Acta Economica et Turistica, 1, 41-59.

6. Cohen, M., \& Bodeher, G. (2008). Understanding the global spa industry: Spa management. Oxford: Elsevier. 
7. Gligorijević, Ž. (2013). Savremeni trendovi $i$ perspektive razvoja turizma [Contemporary trends and prospects for tourism development]. Niš: Ekonomski fakultet.

8. Golja, T., \& Krstinić Nižić, T. (2010). Corporate social responsibility in tourism - The most popular touris m destinations in Croatia. Management, 15(2), 107-122.

9. Hellinger, B., \& Hevel, G. (2010). Priznationo što jeste [Acknowledge what you are]. Beograd: Paideia.

10. Jović, S., \& Stambolović, V. (2013). Tradicionalna, komplementarna i alternativna medicina u Srbiji: legalizacija i integracija u zdravstveni sistem [Traditional, complementary and alternative medicine in Serbia: legalization and integration into the healthcare system]. MD-Medical Data, 5(4), 373-378.

11. Ministarstvo turizma Republike Hrvatske (MINT). (2014). Potpisan UNWTO globalni etičkikodeks u turizmu [UNWTO global code of ethics for tourism signed]. Retrieved July 6, 2019 from http://www.mint.hr/default.aspx?id=19146

12. Ministarstvo zdravlja Republike Srbije [Ministry of Health of the Republic of Serbia]. (2018). Pravilnik o bližim uslovima, načinu i postupku obavljanja metoda i postupaka tradicionalne medicine [Ordinance on the detailed conditions, manner and procedure for performing the methods and procedures of traditional medicine ]. Službeni glasnik Republike Srbije, br.16/2018, Retrieved July 6, 2019 from http://www.zdravlje.gov.rs

13. Narodna skupština Republike Srbije [National As sembly of the Republic of Serbia]. (2019). Zakon o zdravstvenoj zaštiti [Healthcare law]. Službeni glasnik Republike Srbije, br.25/19, Retrieved July 6, 2019 from http://www.zdravlje.gov.rs

14. Nenadović, M.(2007). Medicinska etika [Medical ethics]. Priština: Medicinski fakultet.

15. Oumeish, O. Y. (1998). The philosophical, cultural, and historical aspects of complementary, alternative, unconventional, and integrative medicine in the Old World. Archives of Dermatology, 134(11), 1373-1386.

16. Pokrajac, S., \& Štetić, S. (2017). Osnovi menadžmenta [The basics of management]. Beograd: Vis oka turistička škola strukovnih studija.

17. Presbury, R., \& Edwards, D. (2010). Sustainable operations management. In J. J. Liburd and Edwards, D. (Eds.), Understanding the Sustainable Development of Tourism (pp. 46-66). Oxford: Goodfellow Publishers.

18. Ristić, D. (2004). Osnovi menadžmenta [The basics ofmanagement]. NoviSad:Fakultet za menadžment.

19. Rist, L., \& Schwabl, H. (2009). Komplementarmedizin im politischen Prozess: Schweizer Bevolkerung stimmt uber Verfassungsartikel "Zukunft mit Komplemetarmedizin" ab. Forsch Komplemented [Complementary medicine in the political process: Swiss population votes on constitutional article "Future with complementarymedicine" from. Research complemented]. Retrived February 15, 2020 from http://www.ayrvedaas sociation.eu/files/swiss_referendum_on_cam_forschkomplemented_2009.pdf

20. Sharma, U. (1992). Complementarymedicine today: Practitioners and patients. London and New York: Routledge.

21. Sokolov Milovančević, N., Živanović, N., \& Kitić, A. (2019). New skills needed for managing the health care sector. Ekonomika, 65(4), 75-86. https://doi.org/10.5937/ekonomika1904075S

22. Stambolović, V. (1986). Medicina-nadležnost i alternativa [Medicine - jurisdiction and alternative]. Beograd: Pros veta.

23. Studeli, W. (2009). Switzerland inserts complementary medicine in the constitution. Retrived February 15, 2020 from http://www.jzk.ch/uploads/files/Press release_200905 17_E_international.pdf 
24. Trišić, I., Štetić, S., \& Krstić, V. (2018). Possibilities to prevent negative environmental impacts. Economic of Agriculture, 65(4), 1599-1614. https://doi.org/10.5937/ekoPolj1804599T

25. Trišić, I., \& Stetić, S. (2019). Uticaji etičkih kodeksa na svakodnevni razvoj kulture ponašanja u turizmu [Impacts of codes of ethics on the daily development of a culture of behavior in touris m]. Kultura, 162, 121-135.

26. UNWTO. (1999). Global code of ethics for tourism. The World Touris m Organization. Retrieved July 6, 2019 from http://www.unwto.org

27. Veljković, M., \& Živković, S. (2018). Environmental awareness and well-being as factors of sustainable development. Economics of Sustainable Development, 2(2), 11 17.

28. World Health Organization. (2002). Traditional medicine strategy 2002-2005. World Health Organization.

29. World Health Organization. (2005). National policy on traditional medicine and regulation of herbal medicines: report of a WHO global survey. World Health Organization.

30. Zečević, B. (2004). Okrugli sto natemu: Menadžment u banjskom turizmu i specijalni program u banjama [Round table on the topic: Spa tourism management and spa special program]. Vrnjačka Banja: Turis tička berza banja.

31. Zivanović, S., \& Krstić, V. (2018). Phytotherapy from the aspect of spa tourism. In D. Cvijanović, A. Lemmetyinen, P. Ružić, C. Andreeski, D. Gnjatović, T. Stanišić, A. Mićović (Eds.), Tourism in function ofdevelopment of the Republic of Serbia. Thematic proceedings II (pp. 679-696). Vrnjačka Banja: University of Kragujevac, Faculty of Hotel Management and Tourism in Vrnjačka Banja. 